\title{
Keynote
}

Prologi - puheviestinnän vuosikirja 2020

\section{Työyhteisön vuorovaikutuksen ongelmalähtöinen kehittäminen}

\author{
Leena Mikkola \\ Apulaisprofessori, FT \\ Informaatioteknologian ja viestinnän tiedekunta, \\ Tampereen yliopisto \\ leena.mikkola@tuni.fi
}

Keynote-puheenvuoro Vuorovaikutuksen tutkimuksen päivillä 18.-19.9.2020

Työyhteisöt muodostuvat ja rakentuvat viestinnässä. Siksi yhteisöjen, tiimien ja ryhmien kehittämistä tulee tehdä viestintäteoreettisista lähtökohdista ja viestintäteoreettisin käsittein. Tämä puheenvuoro tarkastelee sitä, kuinka tuota kehittämistä voi toteuttaa. Tässä puheenvuorossa esiteltävä neliportainen analyysimalli on esitelty Tarja Valkosen kanssa kirjoittamassani luvussa Developing workplace communication (Mikkola \& Valkonen, 2020), joka on julkaistu teoksessa Workplace communication (Mikkola \& Valo, 2020). Puheenvuoroni lopussa jäsennän tämän mallin pohjalta kuvausta työyhteisön vuorovaikutuksen kokonaisuudesta.

Työyhteisöissä viestinnän ongelmat ilmenevät usein interpersonaalisessa viestinnässä. Interpersonaalinen viestintä tekee ongelmia näkyviksi, ja on helppo ajatella, että ongelman syy on juuri kyseisessä vuorovaikutussuhteessa.
Voi olla, että vastausta etsitään ja tilannetta selitetään esimerkiksi henkilökemialla, joka ajaa ihmiset jännitteiseen ja konfliktiherkkään suhteeseen: koska kyse on siitä, että kemiat eivät kohtaa, ei asialle voi myöskään mitään tehdä. Tämä suhtautuminen voi osoittaa haluttomuutta tarttua vuorovaikutusongelmiin, mutta se voi olla myös osaamisen puutetta. Monesti onkin niin, että ainoat käsitteet, joilla vuorovaikutusta ja vuorovaikutussuhteita osataan kuvata ovat sen kaltaisia kuten kemia, kohtaaminen ja aitous. Näiden käsitteiden ongelma on siinä, että ne ovat kovin yleisellä tasolla ja siten monimerkityksellisiä. Ne eivät ole teoreettisia käsitteitä, ja niistä voi olla mahdotonta päätellä, millainen viestintäkäyttäytyminen kyseistä käsitettä kuvaa tai ilmentää. Neuvo siitä, että viestintätilanteessa pitää olla aito ei vielä oikeastaan kerro sitä, mitä aitous on, miten "aidosti" toimitaan ja mistä vuorovaikutuskumppani voi päätellä, 
että toinen on aito? Jotta vuorovaikutussuhteissa ilmeneviä ongelmia voi ratkoa, tarvitaan siis viestintäteoreettista osaamista.

Viestintäteoreettinen osaaminen on avuksi myös tilanteissa, joissa ongelman arvellaan olevan "hankalassa ihmisessä". On toki niin, että jotkut yksilötekijät, kuten työntekijän päihdeongelma, voivat olla osasyynä työyhteisön vuorovaikutuksen ongelmiin. Useammin "hankalan ihmisen" osoittamisessa on kuitenkin kysymys attribuutioerheestä. Attribuutioerhe tarkoittaa sitä, että vuorovaikutustilanteessa vuorovaikutuskumppanin käyttäytymistä selitetään yksilön persoonalla (Manusov \& Spitzberg, 2015), vaikka oikeampi selitys löytyisikin tilannetekijöistä kuten työyhteisön rakenteellisista tekijöistä. Yksilökeskeiset selitykset ovat heikkoja selittämään työyhteisön vuorovaikutusta: Ensinnä voi todeta, että yksittäisillä yksilön piirteillä ei ole voitu osoittaa olevan kausaalista seurausta yksilön viestintäkäyttäytymiseen (Daly, 2011). Toiseksi yksilölähtöiset selitykset eivät toimi myöskään tiimien tasolla. Aikaisemmista tutkimuksista tiedetään, että tiimin jäsenten diversiteetti ei ole se selittävä tekijä, joka pystyisi ennustamaan tiimin tuloksellisuutta. Sen sijaan kyse on siitä, miten tiimissä toimitaan ja millaista tiimin jäsenten keskinäinen vuorovaikutus on. (Pennanen \& Mikkola, 2013.)

Työyhteisön viestintäongelmien yksilölähtöiset selitykset selittyvät suurelta osin sillä, että on helpompaa havaita ja nimetä yksilön viestintäkäyttäytymistä kuin vuorovaikutusta: yksilön toimintaa ja hänen responssejaan viestintätilanteissa on helpompaa analysoida kuin useamman vuoron viestintäepisodia puhumattakaan siitä, että analysoisi merkitysneuvottelun etenemistä vuorovaikutustilanteessa. Toisena syynä näen tähän myös yhteiskunnassa vallalla olevan yksilökeskeisyyden, jossa esimerkiksi työssä onnistuminen tai epäonnistuminen tai vastuu omasta työhyvinvoinnista osoitetaan yksilölle itselleen. Vaikka tällä hetkellä yksilökeskeisyys näyttäisi olevan hieman laskussa, kun poikkeuksellinen tilanne korostaa yhteisöllisyyden merkitystä, se ei vielä tarkoita, että työyhteisöissä nähtäisiin, mitkä kaikki tekijät vaikuttavat työyhteisön vuorovaikutukseen.

On siis niin, ettei yksilö voi olla työyhteisön kehittämisen lähtökohta eikä myöskään yksittäinen vuorovaikutussuhde voi sitä olla. Arvelut siitä, että joku pilaa työyhteisön ilmapiirin tai työskentely on hankalaa, koska jotkut eivät tule toimeen toistensa kanssa, eivät auta työyhteisön vuorovaikutuksen kehittämisessä. Yhteisön tai tiimin vuorovaikutuksen kehittämisessä on lähdettävä liikkeelle tehtävästä, työyhteisössä työstä. Työ on se asia, jota varten työyhteisö on. Työyhteisön vuorovaikutuksen kehittämisen tulee perustua viestintäteoreettiseen ajatteluun, ei pseudotieteelliseen persoonallisuustyyppihölynpölyyn tai sellaisiin yleisen tason käsitteisiin, joita ei voi operationaalistaa havaittaviksi. Viestinnän asiantuntijan tulee pystyä siihen, että tulkinnat ovat analyyttisia ja selitykset perustuvat teoriaan sen sijaan, että puhuisimme käsitteillä, joille on vaikea antaa kuvausta ja jotka pahimmillaan mystifioivat vuorovaikutusta. Olennaista on pystyä tekemään ilmiöitä ja ongelmien syitä havaittaviksi.

\section{Työyhteisön vuorovaikutuksen ongelmakohtien analysoiminen}

Jos työyhteisö kaipaa apua siihen, että työyhteisön ilmapiiri on huono, on ensiksi ymmärrettävä, että ilmapiiri on seurausta toiminnasta, ei syy. Sen jälkeen on pyrittävä ymmärtämään, mikä huonoa ilmapiiriä tuottaa, ja löydettävä teoreettisesti pitävä selitys. Tarvitaan analyysitapa, jonka avulla voidaan tunnistaa työyhteisön viestinnän ongelmakohtia. Olen kehittänyt työyhteisöjen vuorovaikutuksen analysointiin 
tarkoitettua neliportaista analyysimallia työskennellessäni työyhteisöjen kanssa ja opettaessani työyhteisöjen kehittämistä. Malli on ongelmalähtöinen, ja se on tarkoitettu käytettäväksi juuri viestintäongelmien syiden tunnistamiseen.

Analyysimalli on eklektinen eli analyysin eri vaiheet nojaavat eri viestintäteorioihin. Ontologisesti ja epistemologisesti mallin perustana on sosio-konstruktionistinen paradigma, ja sen viestintäkäsitys on merkitysorientoitunut (Fairhurst \& Connaugthon, 2014). Perusoletuksena analyysimallissa on se, että työyhteisö syntyy ja rakentuu viestinnässä, joten lähtökohdat palaavat organisaation viestinnällisen konstituoitumisen näkökulmaan (Putnam \& Nicotera, 2010), viestinnän strukturaatioteoriaan (McPhee, Poole, \& Iverson, 2014), systeemiteoriaan (Poole, 2014) ja organisaatiodiskursseihin, mutta mallissa on keskeisessä roolissa interpersonaalinen viestintä ja sen dynamiikka.

Vaiheittaisuus tarkoittaa analyysimallissa sitä, että edetään vaiheittain eri osa-alueiden kautta. Kyseessä ei siis ole viestinnän perinteinen tasoajattelu, joskaan malli ei tätä ajattelua hylkää, koska meillä on eritasoisia sosiaalisia systeemejä kuten suhde tai organisaatio (Bateson, 1983). Perinteiset tasot näen kuitenkin toisiinsa sidoksissa olevina ja keskinäisesti läpäisevinä alueina (Lammers \& Garcia, 2014): esimerkiksi työyhteisön vuorovaikutussuhteeseen heijastuvat ympäröivän organisaation rakenteet ja institutionaaliset tehtävät samalla, kun siihen vaikuttaa se, kuka on vuorovaikutuskumppanina.

Perustehtävän taso. Kun työyhteisössä koetaan vuorovaikutuksen ongelmia tai ongelmia esimerkiksi työn tehokkuudessa, on tarpeen lähteä liikkeelle siitä, miten työ ymmärretään. Mitä työ on ja mistä oikeastaan puhutaan, kun puhutaan työstä? Mikä on työyhteisön jäsenten käsitys perustehtävästä, jota työssä toteutetaan? Mikä on työn tavoite, ja mikä on sen tarkoitus? On havaittu, että työntekijöiden käsitykset yritysten missiosta ja strategiasta eroavat johdon käsityksistä (Kopaneva \& Sias, 2015). On myös hämmentävää, kuinka monesti työstä on eriäviä käsityksiä työyhteisön sisällä. Koska kyse on siitä, onko työyhteisössä yhteinen ymmärrys työstä ja toteutettavasta perustehtävästä, tätä tasoa voi kutsua myös jaetun todellisuuden tasoksi. Yhteistä ymmärrystä perustehtävästä tarvitaan, koska siitä johdetaan työn tavoitteet ja työnjako, jotka tulee yhdessä merkityksentää.

Työyhteisön todellisuuden yhteisesti jakaminen edellyttää jatkuvaa vuorovaikutusta ja siinä tapahtuvaa merkitysneuvottelua. Merkityksistä neuvotteleminen ja niiden tunnistaminen on tärkeää toimivassa työyhteisössä. Esimerkiksi eräässä kulttuurialan työyhteisössä taiteellisen henkilökunnan todellisuutta rakensi voimakas taiteilijuuden diskurssi, joka oikeutti tietynlaisen viestintäkulttuurin, "räiskähtelyn" ja voimakkaat tunneilmaisut. Samalla se kuitenkin loi jännitteitä eri työntekijäryhmien välille, koska markkinointi- ja taloustehtävissä työskentelevät näkivät työpaikkansa aivan eri tavoin kuin taiteellinen henkilökunta. Työyhteisön viestintäongelmat pystyttiin osin palauttamaan näiden eri todellisuuksien olemassaoloon, ja kun ne tunnistettiin, oli mahdollisuus alkaa rakentaa yhteistä ymmärrystä kahden todellisuuden maailman välille.

Analyysin tulokset tällä perustehtävän, siis jaetun todellisuuden tarkastelutasolla kuvaavat sitä, kuinka työ nähdään ja mitä työyhteisö merkitsee sen jäsenille. Samalla analyysi tuottaa tietoa siitä, mistä täytyy keskustella ja millaisia merkitysneuvotteluja tarvitaan. Tämä tieto voi mahdollistaa niiden vuorovaikutuksessa koettujen ongelmien ratkaisemisen, jotka ovat käynnistäneet kehittämistarpeen. Jos tuloksena 
on se, että perustehtävästä, tavoitteesta ja työnjaosta vallitsee yhteisymmärrys, voidaan analyysissa siirtyä seuraavaan vaiheeseen.

Viestintäprosessien taso. Viestintäprosessien tarkastelun lähtökohtana on systeemiteoreettinen ajattelu (Poole, 2014). Tällä tasolla analyysissa on kysymys siitä, kuinka työyhteisön viestintä tukee työprosesseja: kuka tarvitsee tietoa, missä tieto on saatavilla, ja kuka on vastuussa tiedosta, tiedon rakentamisesta ja sen hallinnasta? Viestintäprosessien osalta on tarpeen keskustella myös siitä, kuinka tietoa kannattaa säilyttää ja kuinka sitä jaetaan. Olennaista on myös tiedon laatu eli tiedon oikea-aikaisuus, ajankohtaisuus, relevanssi, luotettavuus, määrä ja allokointi. (Mikkola \& Valkonen, 2020.)

Viestintäprosessien hallinta on työyhteisön epävarmuuden hallintaa. Tämän tason analyysi voi nostaa esille paitsi toimimattomia työprosesseja myös sen, että vuorovaikutuksen jännittyneisyys ja konfliktit voivat kehkeytyä epävarmuudesta ja työ- ja viestintäprosessien yhteensovittamisen ongelmista. Monissa työpaikoissa vuorovaikutuksen ongelmat löytyvät tältä tasolta, kuten erilaisissa kehittämis- ja suunnitteluprosesseissa, joissa toiminta yhtäällä on riippuvaista päätöksenteosta toisaalla.

Organisaatiossa työprosessien hallintaan on pyritty vastaamaan esimerkiksi laatutyöllä. Pelkkä työprosessien analysoiminen ei kuitenkaan tuota hyvää vuorovaikutusta, eikä viestintää voi irrottaa siitä omaksi prosessikseen. Näin ollen tarvitaan yhteistä tarkastelua. Vuorovaikutuksen näkökulmasta kyse on siitä, millaisia merkityksiä työprosessit saavat ja kuinka viestintä tukee niitä eri vaiheissa. Mikäli huomataan, että työ- ja viestintäprosessit kytkeytyvät toisiinsa tarkoituksenmukaisella tavalla, voi analyysissa edetä tarkastelemaan käytänteiden tasoa.
Viestintäkäytänteiden taso. Viestintäkäytänteiden tarkasteleminen perustuu viestinnän strukturaatioteorian ideaan (Poole \& McPhee, 2005). Tällä tasolla analyysi kohdentuu viestintä- ja vuorovaikutusrakenteisiin. Rakenteet muodostuvat säännöistä, jotka ovat usein piiloisia, toimintaamme ohjaavia rakenteen osia, ja käytänteistä, joista säännöt voi tunnistaa (Poole \& McPhee, 2005). Joskus säännöt ovat tietoisia, niistä puhutaan, sovitaan, ja niiden mukaan toimitaan. Työyhteisön vuorovaikutusta voivat kuitenkin ohjata myös vanhentuneet säännöt tai täysin tiedostamattomat oletukset. Tunnistamalla näitä käytänteitä niitä havainnoimalla, voimme muuttaa myös sääntöjä, mikä tapahtuu toimimalla toisin (Arrow, Henry, Poole, Wheelan, \& Moreland, 2005). Vähitellen käytänteiden muuttaminen alkaa heijastua myös siihen, mitä pidetään hyvänä ja sopivana viestintänä työyhteisössä.

Työyhteisössä on moninaisia rakenteita, jotka kytkeytyvät toisiinsa. Vuorovaikutusrakenteilla on tässä keskeinen asema: valta-, normi- ja roolirakenteet muodostuvat vuorovaikutuksessa nekin, joten niitä voidaan pyrkiä muuttamaan muuttamalla vuorovaikutusrakenteita. Analyysissa kannattaa keskittyä tunnistamaan tarkoituksenmukaisia ja ei-tarkoituksenmukaisia käytänteitä. Yksittäisiä käytänteitä on tarkasteltava myös osana kokonaisuutta. Emme voi suoraviivaisesti ajatella, että tietäisimme, minkälaisia funktioita käytänteet palvelevat. Esimerkiksi kokoukset on usein nähty prosessien toteuttamisena, tiedonhallinnan ja ongelmanratkaisuprosessien areenana, mutta kokous voi olla myös käytänne, joka vahvistaa relationaalisia tavoitteita työyhteisössä. Se voi myös olla identiteettitavoitteita vahvistava käytänne organisaatiossa. (Laapotti \& Mikkola, 2016.)

Monet työyhteisön vuorovaikutuksen ongelmista kytkeytyvät viestintäkäytänteiden tasolle. 
Epäselvät käytänteet vaikeuttavat työstä suoriutumista ja aiheuttavat turhautumista, mikä puolestaan heijastuu takaisin vuorovaikutukseen. Jos kuitenkin tällä tasolla viestinnän koetaan tukevan perustehtävän toteuttamista ja vuorovaikutuksen olevan toimivaa, voidaan analyysissa siirtyä tarkastelemaan seuraavaa vaihetta.

Interpersonaalinen taso. Kun siirrytään tarkastelemaan interpersonaalisen viestinnän tasoa työyhteisössä, on tarkastelukohde kaikkinensa laaja ja todella moniulotteinen: interpersonaalisen viestinnän dynamiikka heijastuu kaikkeen työyhteisön toimintaan ja viestintään. Se näkyy ja vaikuttaa monella tapaa. Työyhteisön kannalta keskeisiä ilmiöitä ovat esimerkiksi vuorovaikutussuhteet, joissa kiteytyvät odotukset työtovereita kohtaan. Tärkeitä intepersonaalisia ilmiöitä ovat myös luottamus, supportiivinen viestintä, konfliktien hallinta ja kiinnittyminen. Analyysiprosessin edetessä muista vaiheista kertyy jo tietoa siitä, millaiset interpersonaaliset kysymykset voivat olla olennaisia. Interpersonaalisella tasolla analyysi etenee työyhteisöä havainnoimalla ja kuuntelemalla. Erilaisia havaintoja voi testata peilaamalla niitä teoreettiseen tietoon.

On mahdollista, että työyhteisön vuorovaikutuksen koettujen ongelmien ratkaisut ovat löytyneet jo analyysin aiemmissa vaiheissa muilta tasoilta. Interpersonaalisten kysymysten äärellä on kuitenkin tärkeä viipyä ja esittää kysymys siitä, miten työyhteisön interpersonaalinen viestintä edistää tai haittaa työn tavoitteiden saavuttamista. Keskeisiä kysymyksiä ovat myös työyhteisön ja sen jäsenten vuorovaikutusosaaminen (Mikkola \& Valkonen, 2020) sekä vuorovaikutuseettiset kysymykset, kuten yksilön oikeus säädellä yksityisyyttään (Omdahl, 2006).

\section{Työyhteisön vuorovaikutuksen viestintäteoreettinen kehittäminen}

Edellä esitelty analyysimalli on tarkoitettu välineeksi viestintä- ja vuorovaikutusongelmien sijainnin tunnistamiseen. Mallin tarkoitus on helpottaa vuorovaikutusongelmien palastelua ja systemaattista etenemistä. Lähtökohtana on epäillä ilmeistä ja kääntää tarkastelu yksilöstä ja interpersonaalisesta tasosta perustehtävään, viestintäprosesseihin ja viesintäkäytänteisiin. Kyseessä on yksi tapa soveltaa viestinnän teoriaa työyhteisöjen vuorovaikutuksen analysointiin. Kun ongelmakohtia on havaittu, alkaa varsinainen kehittämistyö. Se tähtää työyhteisön viestinnän uudistamiseen, ja se tulisi aloittaa siltä tasolta, jolla ongelmia on havaittu. Hyvin usein se on perustehtävän taso, jolla tarvitaan merkitysten yhteensovittamista. Varsinainen kehittämistyö tapahtuu aina työyhteisön vuorovaikutuksessa ja voi edetä kaikilla tasoilla yhtäaikaisesti. Esimerkiksi perustehtävän pohtimiseen voi kytkeä viestintäkoulutusta, ja viestintäkäytänteitä voi pohtia yhtä aikaa supportiivisen viestinnän kehittämisen kanssa.

Kuvioon 1 on koottu työyhteisön kehittämisen alueet. Työyhteisön sosiaalisen todellisuuden voi nähdä merkitysympäristönä, joka rakentuu historiallisissa ja kulttuurisissa diskursseissa. Tämä merkitysympäristö tuottaa työyhteisön tehtävän ja tavoitteen, jotka ohjaavat viestintäprosesseissa todentuvaa toimintaa. Työhön kytkeytyvät viestintäprosessit suuntaavat vuorovaikutusta, ja vuorovaikutus puolestaan rakentaa ja muokkaa merkitysympäristöä. Vuorovaikutuksessa rakenteistuvat käytänteet, jotka sulautuvat osaksi merkitysympäristöä. Merkitysympäristö ja vuorovaikutus ovat jatkuvasti yhteydessä toisiinsa tuottaen merkityksiä ja vaikuttaen merkitysten rakentumiseen. Kuvio pyrkii kuvaamaan siis sitä, että vaikka eri tasot - tai alueet - on mahdollista erottaa analysoi- 
taessa niitä, kaikki alueet kytkeytyvät toisiinsa ja läpäisevät toisensa, ja merkitykset luodaan työyhteisön viestinnässä monissa prosesseissa.

\section{Viestintäteoreettinen \\ kehittäminen - kehittäjän, kouluttajan, johtajan ja tutkijan tehtävä}

Kehittäjälle tässä puheenvuorossa esitelty analyysimalli on työkalu. Koska analyysin lähtökohtana on viestinnälle annettavien ja vuorovaikutuksessa rakennettavien merkitysten tarkastelu, on tarpeen huomioida kaksi asiaa: aika ja eettisyys.

Kevään poikkeusolot saivat nopeasti tutkijat liikkeelle ja lyhyessä ajassa kerättiin paljon aineistoja työyhteisöjen toiminnasta ja sopeutumisesta tilanteeseen. Menetelmät valittiin ja asetelmat rakennettiin nopeasti, jotta päästiin kiinni akuuttiin vaiheeseen. Näitä aineistoja kerättiin myös kehittämistarkoituksessa. Tämä herätti minussa pohdintaa siitä, mikä on sellaista organisaation sisäistä tietoa tai tarvetta, joka oikeuttaa tiedon keräämiseen kriisitilanteessa. Kehittämisen aikajänne on pitkä ja asiat merkityksentyvät hitaasti, eikä kehittämistä tehdä kyselyillä vaan keskustelulla. Kehittäminen tarvitsee aikaa merkityksistä neuvottelemiselle, mikä voi myös kuormittaa - näin aika ja eettisyys kietoutuvat toisiinsa. Analyysimalli tähtää siihen, että työyhteisöjä kehitettäessä ei korjailla hetkittäisiä oireita, laastaroida, vaan puututaan todellisiin syihin oireiden tai ensiavun sijaan.

Opetuksen ja koulutuksen rooli kehittämisen näkökulmasta on se, että koulutuksessa tarjotaan tietoa viestintäteoreettisista käsitteistä ja selitystavoista. Teoreettisen ymmärryksen rakentaminen mahdollistaa sen, että työyhteisöissä ja työntekijöillä on välineitä vuorovaiku-

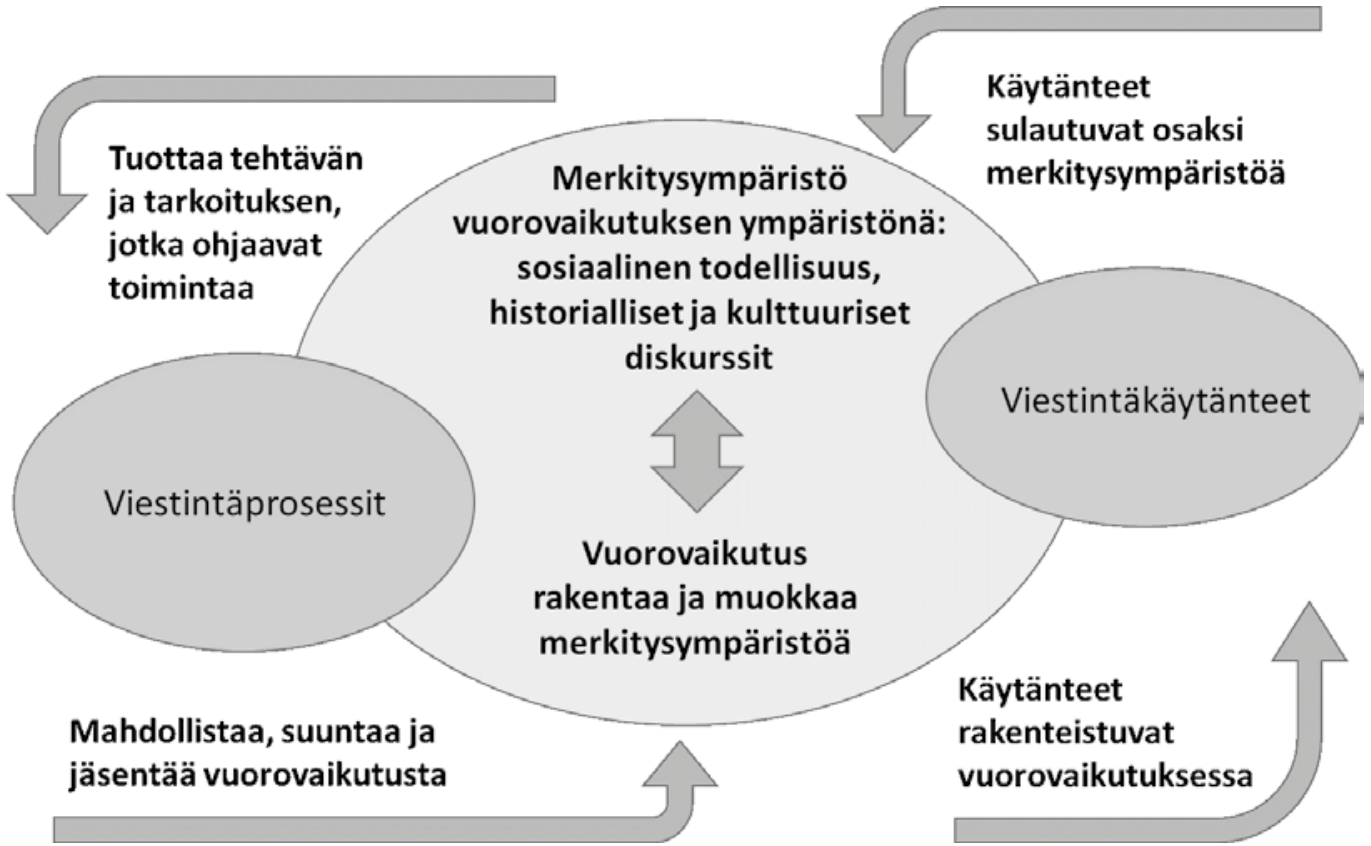

Kuvio 1. Työyhteisön rakentuminen viestinnässä. 
tuksen ymmärtämiseen. Analyysimalli voi tarjota myös välineen työyhteisön kokonaisuuden ymmärtämiseen kontekstina. Työyhteisö muodostaa monitahoisen kontekstin, jossa eri alueet ovat keskinäisesti riippuvaisia ja läpäiseviä.

Johtajuuden näkökulmasta analyysimalli tarjoaa jäsennyksen johtajan viestintätehtävistä. Kun johtajuus on sosiaalista vaikuttamista ja tavoitteiden kannalta merkityksellisiksi tunnistettuja tekoja (Fairhurst, 2007), malli voi tarjota yhden tavan hahmottaa, mitä on vuorovaikutuksen ja viestinnän johtaminen työyhteisössä. Ymmärrys viestintäprosessien ja viestintäkäytänteiden merkityksestä on suuri niin johtajuuden kuin johtamisen (management) näkökulmasta, joka sekin tapahtuu vuorovaikutuksessa.

Tällä hetkellä johtajan keskeinen tehtävä on ylläpitää merkitysneuvotteluja, ja haasteena on se, että merkitysten tiheys säilyy. Etätyö - huolimatta siitä, että se voi toimia erinomaisesti - kuluttaa ja ohentaa työhön liittyviä merkityksiä, koska monet merkitysneuvottelut jäävät käymättä: vuorovaikutukselle tyypillinen puheenvuorojen vaihtuminen muuttuu ja päällekkäin puhuminen - kiistäminen ja vahvistaminen - jäävät puuttumaan. Vaikka etäyhteydessä edelleen syntyy relationaalista viestintää, ja relationaalisia sanomia tuotetaan, tapahtuu hiljattaista merkitysten eroosiota, kun keskusteluun ei enää niin helposti synny tihentymiä. Johtajan tärkeimpiä tehtäviä vuorovaikutuksen ylläpitämisessä ja kehittämisessä voi olla merkitysten jakamisesta huolehtiminen. Kun palataan etätyöstä työpaikoille, kannattaa käydä keskusteluja siitä, missä nyt ollaan ja mitä ollaan tekemässä.

Tutkijoille työyhteisön vuorovaikutuksen viestintäteoreettinen kehittäminen tuottaa haasteen tehdä soveltavaa tutkimusta - ja toisaalta etsiä soveltavasta tutkimuksesta teoreettisia avauk- sia. Toimintatutkimus ja etnografisten menetelmien käyttö, siis tutkimuksen nivominen kehittämistoimintaan, tarjoaa sekä teoreettista ymmärrystä että sovellettavaa tietoa työyhteisöjen viestinnästä. Tässä ajassa - vankan eettisen harkinnan oikeuttamana - merkitysneuvotteluiden tutkiminen digitaalisista aineistoista tarjoaa varmasti kiinnostavaa tietoa keskustelun dynamiikasta ja sen merkityksestä työyhteisöille.

Tässä puheenvuorossa olen kuvannut analyysimallin työyhteisön vuorovaikutusongelmien analysoimiseksi ja siitä johdetun kokonaiskuvauksen työyhteisön viestinnän moninaisuudesta. Mallia voidaan käyttää työyhteisön vuorovaikutuksen kehittämisen tukena ja sitä voidaan soveltaa eri tavoin. Ongelmanratkaisu ja kehittäminen edellyttää näiden kaikkien osa-alueiden tunnistamista, analyysia ja huomioimista. Tarkoitukseni on jatkaa mallin kehittämistä ja myös sen empiiristä ja teoreettista perustelemista. Olen iloinen siitä, että Vuorovaikutuksen tutkimuksen päivät on tarjonnut mahdollisuuden käydä mallista keskustelua, kehittäminen ja kehittyminen vaatii sitä.

Kiitän Prologoksen johtokuntaa ja Vuorovaikutuksen tutkimuspäivien järjestelytoimikuntaa kutsusta ja mahdollisuudesta puhua tästä aiheesta. Kiitän myös Tarja Valkosta, joka on kirjoittanut kanssani analyysimallista. Maarit Valoa kiitän toimittajan tarkkanäköisistä kommenteista malliin. 


\section{Kirjallisuus}

Arrow, H., Henry, K. B., Poole, M. S., Wheelan, S., \& Moreland, R. (2005). Traces, trajectories, and timing: The temporal perspective on groups. Teoksessa M. S. Poole, \& A. B. Hollingshead (toim.), Theories of small groups. Interdicplinary perspectives (s. 313-368). Thousand Oaks, CA: Sage.

Bateson, G. (1983). Information and codification: A philosophical approach. Teoksessa J. Ruesch, \& G. Bateson (toim.), Communication. The social matrix of psychiatry (3. painos) (s. 168-211). New York: Norton.

Daly, J. A. (2011). Personality and interpersonal communication. Teoksessa L. L. Putnam, \& D. K. Mumby (toim.), The Sage handbook of organizational communication: Advances in theory, research, and methods (s. 131-168). Thousand Oaks, CA: Sage.

Fairhurst, G. T. (2007). Discursive leadership: In conversation with leadership psychology. Thousand Oaks, CA: Sage.

Fairhurst, G. T., \& Connaughton, S. (2014). Leadership communication. Teoksessa L. L. Putnam, \& D. K. Mumby (toim.), The Sage handbook of organizational communication: Advances in theory, research, and methods (s. 401-423). Thousand Oaks, CA: Sage.

Kopaneva, I., \& Sias, P. M. (2015). Lost in translation: Employee and organization construction of mission and vision. Management Quarterly, 29(3), 358-384. https://doi.org/10.1177/0893318915581648

Laapotti, T., \& Mikkola, L. (2016). Social interaction in management group meetings: A case study of a Finnish hospital. Journal of Health Organization and Management, 30(4), 613-629. http://doi.org/10.1108/JHOM-02-2015-0040
Lammers, J., \& Garcia, M. A. (2014). Institutional theory. Teoksessa L. L. Putnam, \& D. K. Mumby (toim.), The Sage handbook of organizational communication (s. 195-216). Thousand Oaks, CA: Sage.

Manusov, V., \& Spitzberg, B. (2015). Attribution theory: Finding good cause in the search for theory. Teoksessa D. O. Braithwaite, \& P. Schrodt (toim.), Engaging theories in interpersonal communication: Multiple perspectives (s. 37-50). Los Angeles, CA: Sage.

McPhee, R. D., Poole, M. S., \& Iverson, J. (2014). Structuration theory. Teoksessa L. L. Putnam, \& D. K. Mumby (toim.), The Sage handbook of organizational communication: Advances in theory, research, and methods (s. 75-99). Thousand Oaks, CA: Sage.

Mikkola, L., \& Valkonen, T. (2020). Developing workplace communication. Teoksessa L. Mikkola, \& M. Valo (toim.), Workplace communication (s. 179-192). New York: Routledge.

Mikkola, L., \& Valo, M. (toim.) (2020). Workplace communication. New York: Routledge.

Pennanen, E., \& Mikkola, L. (2013). Vuorovaikutus hallinnollisissa ryhmissä. Hallinnon Tutkimus, 32, 229-242.

Poole, M. S. (2014). Systems Theory. Teoksessa L. L. Putnam, \& D. K. Mumby (toim.), The Sage handbook of organizational communication: Advances in theory, research, and methods (s. 49-74). Thousand Oaks, CA: Sage.

Omdalh, B. L. (2006). Toward effective work relationships. Teoksessa J. M. H. Fritz, \& B. L. Omdahl (toim.), Problematic relationships in the workplace (s. 277-294). New York, NY: Peter Lang,

Putnam, L. L., \& Nicotera, A. M. (2010). Communicative constitution of organization is a question: Critical issues for addressing it. Management Communication Quarterly, 24(1), 158-165. 